\title{
FACTORS AFFECTING SMOKED FISH QUALITY: A REVIEW
}

\author{
*Santa Puke, Ruta Galoburda \\ Latvia University of Life Sciences and Technologies, Latvia \\ *Corresponding author's email: santa_puke@inbox.lv
}

\begin{abstract}
Smoked sprats (Sprattus sprattus balticus) from the Baltic sea are one of the most popular processed fish products in Latvia. The amount of catching and demand is annually increasing. For producers, it is important to provide stable quality throughout the year, which sometimes is challenging due to many factors. Smoked fish quality depends not only on the seasonality, but also on the applied technologies. The aim of the current study was to review research findings about factors affecting the smoked fish quality. The databases of Science Direct, Web of Science, Wiley Online Journals and Google Scholar were searched. The first parameter that affects quality of fish till processing is raw material, its catching place and season, as well as whether it is fresh or frozen fish, that includes not only microbiological parameters, but also physical and chemical changes in fish depending on the storage conditions. The second parameter is the applied pre-treatment methods (using salt, acids) before processing, which can improve fish texture and make better result for smoked fish. The third parameter is the used technology for the fish processing, heat treatment methods use of wood chips or liquid smoke, or adjustment of smoking conditions. These all together make a lot of sensorial and textural changes in the final product. If any of these parameters is changed during processing, they can affect the smoked fish quality. Therefore, to ensure constant quality of smoked fish, in-depth knowledge of parameters is extremely important.
\end{abstract}

Key words: pre-treatment, smoked sprat, seasonality, fresh and frozen sprats, smoking.

\section{Introduction}

Each year catching amount of sprats (Sprattus sprattus balticus) is increasing because of increased consumption of fish products. Besides the increased consumption, customers pay more attention to the quality - sensory parameters including textural parameters (consistency, juiciness) as well as nutritional components (lipids, protein). Fish consumption has a positive effect on human health. It is nutritionally valuable product, and good source of protein; it also contains valuable lipids (omega-3 fatty acids), minerals and vitamins (Mohanty et al., 2019). Fish lipids contain polyunsaturated fatty acids (PUFA) with up to 6 double bonds - eicosapentaenoic acids (EPA) and docosahexaenoic acid (DHA) (Stołyhwo, Kołodziejska, \& Sikorski, 2006).

Sprats are small commercial fish from Clupeidae family and their size from the sea is about $10-20 \mathrm{~cm}$. They live in shoals and feed on zooplankton, spawning season usually varies depending on a geographical location, but in the Baltic sea it is from March till June (Timberg et al., 2014). Sprats contain a lot of water (57-73\%) and lipids $(10-24 \%)$. There is inverse relationship between water and lipids, which means that lower water content makes higher lipid content and contrary (Timberg et al., 2011). Sprats are rich in vitamin $\mathrm{D}$, minerals like potassium, iron, zinc, iodine (Usydus, Szlifder-Richert, \& Adamczyk, 2012). Baltic sprats are rich source of PUFA and stability of these fatty acids is influenced by the storage conditions and pre-treatment methods.

Raw product quality is the main parameter, which affects finished products quality. Fish is easily spoiled due to oxidation and developing offflavours. Cooling can maintain freshness, but it does not eliminate microorganisms or enzymatic activity, the psychotropic bacteria will still live under chilled conditions (Wu, Pu, \& Sun, 2019). As quality changes along the year, it is important to find the main technological parameters, which should be adjusted to ensure constant quality of the final product.

The aim of the current study was to review research findings about factors affecting the smoked fish quality.

\section{Materials and Methods}

The research was performed by using monographic method to review factors influencing smoked fish quality. The databases of Science Direct, Web of Science, Wiley Online Journals and Google Scholar were searched. No time restrictions were applied, and all articles were selected in January - February, 2020. The aim of the current study was to review research findings about factors affecting the smoked fish quality parameters, which can affect the quality of the product, find out the main quality parameters, and determine how to ensure the constant quality using some pre-treatment methods or selecting the most appropriate heat treatment method.

\section{Results and Discussion}

The smoked fish quality depends on various factors, which can be grouped as shown in Figure 1. To provide constant quality of the finished product all parameters should be considered and necessary adjustments made in the processing technologies.

\section{Raw material}

The raw material quality is the main factor affecting smoked fish quality. Raw material quality has intrinsic factors like size, fat content and skin properties, that 


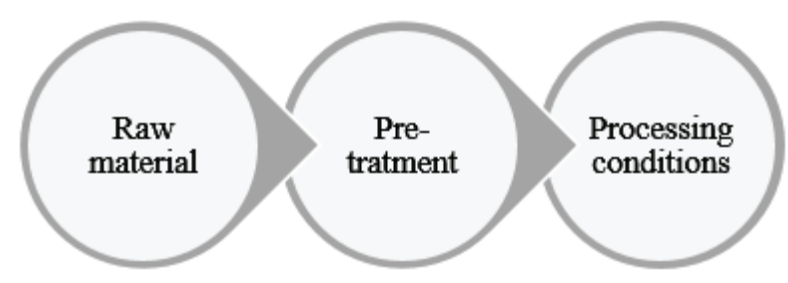

Figure 1 . The main factors affecting smoked fish quality.

mean small fish like sprats spoil faster than large fish (Zugarramurdi et al., 2004). Quality parameters are affected by seasonality, sex, age, and geographical location, these all make changes in fish lipids and proteins (Abbas et al., 2008). Sprats are fatty fish and valuable dietary source of proteins, polyunsaturated fatty acids from n-3 family. Cooling or transporting conditions have great influence on processed fish quality. Fatty fish does not store as long as lean fish in aerobic conditions, because of fat oxidation processes. They also have higher influence on the quality of final products (Zugarramurdi et al., 2004). There are no correlations established between lipid oxidation and content of lipids in thawed fish. Temperature and some smoke compounds can affect fish lipids and proteins (Kołodziejska \& Sikorski, 2004).

According to Timberg et al. (2011) in spring, when is spawning season, the Baltic sprat lipid content was low $13 \pm 1.6 \%$, but in autumn, end of feeding season (October, November) the highest $22 \pm 3 \%$. Similar trend was reported by Usydus, SzlifderRichert, Adamczyk (2012), see Table 1. Protein was stable through seasons, being about $15 \%$. That means that autumn sprats (the end of feeding season and all wintering season) have the highest lipid content, but in spring (spawning season) - the highest water content. In spring and summer, the content of lipids is the lowest and it has influence on the textural and sensorial properties. It makes changes in sensorial parameters - less intense aroma and flavour and makes softer texture (Timberg et al., 2011). Additionally, it has been reported that proximate composition and fatty acids profile in muscle depend on seasonality of Baltic sprats. Fish up to $10 \mathrm{~cm}$ have different indicators than class 10-13 and over $13 \mathrm{~cm}$ (Usydus, Szlifder-Richert, \& Adamczyk, 2012).

Raw material freshness and quality of the finished product have close relationship. For all fish products, its freshness has the most essential role. It includes shelf life of fish, bacterial flora, and storage conditions. Abbas et al., (2008) reported that pH of European sea bass (Dicentrarchus labrax) increased from 6.39 till 6.69, trimethylamine $-\mathrm{N}$ (from trimethylamine

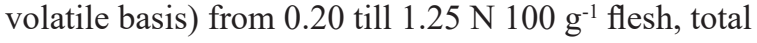

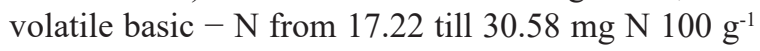
flesh, free fatty acids from 1.78 till $2.73 \mathrm{~g}$ oleic acid per $100 \mathrm{~g}$ lipids, but content of trimethylamine oxide

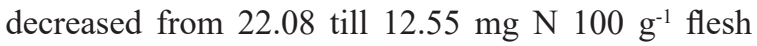
during storage period from 1 till 22 days in ice. Initial $\mathrm{pH}$ decrease occurs because glycogen in the fish muscle has been metabolized to lactic acids. Fresh live fish $\mathrm{pH}$ is 7 , and during further storage it increases

\section{Proximate nutritional composition in muscle of Baltic sprat depending on catch season}

(Usydus, Szlifder-Richert, \& Adamczyk, 2012)

\begin{tabular}{|l|c|c|c|}
\hline \multicolumn{1}{|c|}{ Indicator } & $\begin{array}{c}\text { Feeding season } \\
\text { (July - October) }\end{array}$ & $\begin{array}{c}\text { Wintering season } \\
\text { (November - February) }\end{array}$ & $\begin{array}{c}\text { Spawning season } \\
\text { (March - June) }\end{array}$ \\
\hline Moisture, \% & $66.40 \pm 1.69$ & $70.71 \pm 2.43$ & $77.48 \pm 1.81$ \\
\hline Protein, \% & $17.06 \pm 0.46$ & $16.74 \pm 0.41$ & $16.61 \pm 0.33$ \\
\hline Lipid, \% & $15.46 \pm 2.02$ & $11.34 \pm 2.07$ & $5.10 \pm 0.87$ \\
\hline Saturated fatty acids, \% & $28.37 \pm 0.24$ & $29.08 \pm 1.55$ & $28.64 \pm 2.12$ \\
\hline $\begin{array}{l}\text { Monounsaturated } \\
\text { fatty acids, \% }\end{array}$ & $32.78 \pm 1.07$ & $31.56 \pm 5.96$ & $35.63 \pm 4.41$ \\
\hline $\begin{array}{l}\text { Polyunsaturated } \\
\text { fatty acids\%, including: }\end{array}$ & $38.85 \pm 0.96$ & $39.28 \pm 4.73$ & $35.75 \pm 2.36$ \\
\hline -eicosapentaenoic acid, \% & $8.40 \pm 0.65$ & $8.05 \pm 1.42$ & $4.97 \pm 1.29$ \\
\hline -docosahexaenoic acid, \% & $17.67 \pm 0.69$ & $18.17 \pm 2.20$ & $17.93 \pm 1.18$ \\
\hline Individual weight, g & $12.48 \pm 2.87$ & $12.38 \pm 4.03$ & $12.00 \pm 1.93$ \\
\hline
\end{tabular}


because of production of alkaline enzymes, and if fish spoiling starts, there can be an increase in total volatile basic - N. Abbas et al. (2008) suggest to use fish pH as an indicator of fish freshness.

Wild fish can be harvested by a large variety of methods. To control stress produced by these conditions, it is necessary to control mainly fishing method and time. Incorrect handling can determine the quality changes during storage. If fish are caught in a highly stressed state, their lactic acid produced in muscle combined with high muscle temperature results in a dull muscle, and it makes acidic or metallic aftertaste (Borderías \& Sánchez-Alonso, 2011). In this case, rigor mortis proceeds faster and quality is lower. The stiff and rigid condition of muscle tissues is rigor mortis, it starts about 1 till 6 hours after death (Hamada-Sato et al., 2005). If large fish are killed faster, stress is less and quality is better. Stress before catching and before death have effect on quality. From biochemical factors after catch, its muscle cells contain more lactic acids from anaerobic respiration and rigor mortis sets sooner. Post-mortem $\mathrm{pH}$ in fish flesh on fish catching vessels have the effect on texture of fish, in that case it is very important to make faster cooling on vessels (Zugarramurdi et al., 2004). Chilling rate has an important role in the final product quality and especially in texture. In highly stressed fish all muscles enter rigor mortis very quickly all fish go very stiff and difficult to process. Texture of stressed fish was softer during storage (Borderías \& Sánchez - Alonso, 2011).

Spoilage of fish starts as soon as the fish die after fishing, and spoilage varies with species, handling methods, hygienic and chilling conditions and methods; there is an influence from microorganisms (Solanki et al., 2016). Thiobarbituric acid (TBA) and peroxide value (PV) are two commonly used parameters for the evaluation of lipid oxidation and decomposition of protein ( $\mathrm{Wu}, \mathrm{Pu}, \&$ Sun, 2019).

High moisture content and nutrients in fish facilitate the growth of many microorganisms including pathogens (Listeria monocytogenes, Escherichia coli, Salmonella spp.), which can affect not only the fish quality, but also product safety. Listeria spp. and Salmonella spp. are naturally present in aquatic environment and their presence can be contaminated with already infected fish. Escherichia coli indicates poor hygiene conditions during storage or transporting (Eizenberga et al., 2015). As sprats are cold-water fish, they can carry Shewanella putrefaciens and can spoil faster than warm water fish. Storage conditions using $40 \%$ ice and $60 \%$ water or with additionally injected ozone can increase shelf life up to $13-16$ days, but it is prolonged by 8 days when normal ice is used. Ozone and organic acids have natural antioxidants (Sampels, 2015b). Free histidine is generally found in fatty fish, red meat fish and Enterobacteriaceae, Clostridium and Lactobacillus produce histidine decarboxylase and for growing histamine forming bacteria most important is coliform bacteria. Histamine forming bacteria naturally exist on the gills and in salt water fish. Only rapid chilling after catch immediately can prevent forming of these bacteria, and enzyme, bacteria can be inactivated by cooking, but once histamine is produced, it cannot be eliminated by heating or freezing. Fish may contain pathogenic bacteria Clostridium botulinum (type E), Staphylococcus aureus, Vibrio parahaemolyticus and it grows in raw fish. Its growth is decreased in frozen fish, or in cold storage $\left(0\right.$ till $\left.4{ }^{\circ} \mathrm{C}\right)$ (Köse, 2010). In fresh fish (sprats) the histamine was detected from 5 samples in 3 samples when fish were smoked. And if in fresh fish amount of histamine were determined 1.4 till $5.2 \mathrm{mg} \mathrm{kg}^{-1}$, in smoked it increased to 1.8 till 24.1 $\mathrm{mg} \mathrm{kg}^{-1}$ (Pawul-Gruba, Michalski, \& Osek, 2014).

Freezing and thawing of raw material

Freezing slows the biological, chemical, and physical deterioration of food, degradation of food quality (colour, texture, lipid oxidation, enzymatic activity). Quality loss in frozen fish has been attributed to protein denaturation, which correlates strongly with loss of sensory quality. During freezing microbiological growth is suspended, but not enzymatic activity (RuizCapillas, 2000). Biological and chemical reactions such as enzymatic activity and lipid oxidation have significant impact on fish quality during long-term frozen storage. The total lipid and ash content vary with size and catching season of the fish. Storage time and temperature affect quality loss and the shelf life of fish, lipid content decreased from $9.72 \%$ till $7.20 \%$ in tilapia (Oreochromis niloticus) (Dawson, AlJeddawi, \& Remington, 2018). Red muscles contain high levels of lipids and are sequentially subject to lipid oxidation. Trimethylamine oxides are found within the red muscle that can be enzymatically or non-enzymatically degraded, resulting in products such as dimethylamine and formaldehyde. Some researchers - Dawson, Al-Jeddawi, \& Remington (2018) - found fatty acid (C16:1) decrease in meat fat during frozen storage, while no decrease in polyunsaturated fatty acids (PUFA). Peroxide value is an early indicator of oxidation.

Freezing preserves fish longer time, but it also may have negative effect on structural and chemical properties of muscle. The faster and more homogeneous freezing proceeds, the smaller ice crystals are made and it makes less textural damage to muscle fibre (Sampels, 2015b). Slow freezing can result in formation of big ice crystals, which can destroy cell membranes and it increases a risk of oxidation, texture damage and loss of water holding capacity. During frozen fish storage it is very important to keep stable temperature to prevent 
the growth of ice crystals (Sampels, 2015a). During thawing, ice crystals melt, and if formed intracellularly or around muscle tissue, moisture would remain within the fish. Water holding capacity is commercially very important to appearance and texture.

Frozen fish storage leads to reduction of protein extractability and reduction of water holding capacity. Freezing before smoking has small physicochemical characteristic on flesh. In frozen fish storage, the myofibrillar proteins can lead to denaturation in the functional properties of fish muscle proteins and make changes in texture due to the loss of water holding capacity. Protein denaturation reduces amount of soluble proteins. Freezing before smoking has a negative effect on fish flesh adhesiveness, cohesiveness (textural properties), smoke odour intensity and colour intensity (Martinez et al., 2010). Generally, sprats made from frozen thawed raw materials has the same texture as the same product made from fresh sprats. However, it is possible that sprats made from frozen thawed fish had a tendency to be harder and sour, the rancid taste developed more rapidly than samples made from fresh fish. Freezing and thawing may damage the protein native structure making it susceptible to further reactions (Timberg et al., 2014).

\section{Pre-treatment methods}

Preserving fisheries products for a long storage time can be done by either lowering water activity $\left(a_{w}\right)$ or changing $\mathrm{pH}$ of products. Preservation can also be carried out by applying antibacterial activity of salt and smoke components. Pre-treatment methods have not only preservation options, but also provide better sensorial properties of products.

Salting is one of the traditional preservation processes, when salt works as preservative that penetrates the tissue. Salt separates water from fish and replaces it with salt. Thus, water concentration in fish decreases. During salting, water activity $\mathrm{a}_{\mathrm{w}}$ can reach 0.8 to 0.7 . (Many pathogenic organisms cannot survive these conditions. Salting protected chub mackerel from oxidation (Sampels, 2015a). Replacing $\mathrm{NaCl}$ to $\mathrm{KCl}$ as well as the addition of ascorbic acid to the brine solution decreased lipid oxidation in salted mackerel. Replacing sodium with potassium about $25 \%$ can reduce amount of sodium in human dietary, but sodium and potassium have similar properties. If the amount is more than $25 \%$, it makes a bitter taste. The uptake of salt into fish muscle depends on salting procedure, salt concentration used in brine, fish species, size, thickness. Protein loss depends also on the salt content (Sampels, 2015a). The size, thickness of the fish, with or without skin and scales, if fish is or not in rigor mortis, the freshness of fish it all affects the ripening process. The ripening of salted fish is a biochemical process, where enzymes cause degradation of fish muscle compounds. If $\mathrm{pH}$ increases, the quality of fish decreases (Bonoco \& Kurt Kaya, 2018). Salting preserves fish from decomposition and minimize oxidation of the lipids. It reduces moisture in fish muscle. During salting characteristic flavour and texture of finished products are developed.

Brine concentration and brining time affected the texture development. There is little information about salt concentration effect on the shelf life of smoked fish (Yanar, Çelik, \& Akamca, 2006). The flavour, odour and texture changed during the storage at rates depending on the storage temperature. The higher salt concentrations prevented some growth of halophiles. Storage in lower temperature with higher salt concentration increased shelf life of brined anchovies (Karaçam, Kutlu, \& Köse, 2002). The highest water content in canned catfish was in 3\% brine solution. That means that the use of different brine concentration of solution has an effect on nutrient values (Herawati et al., 2016).

Marinating preserves fish through the simultaneous action of salt and organic acids. Marinating is used to tenderize, change textural and structural properties of raw material. It increases ionic strength and decreases the $\mathrm{pH}$, it also makes tender texture, better structural properties and changes the taste (Çağlak, 2015). Salt and acids diffuse into the fish muscle, denature the protein and lower the $\mathrm{pH}$ value and activating the lysosomal cathepsins, which makes typical flavour. Texture is very important quality parameter. Low $\mathrm{pH}$ induced protein denaturation and makes harder texture (Serdaroglu et al., 2015). Marinating improves flavour and textural properties, it slows down the bacterial and enzyme activity and provides taste, tenderness, textural and structural changes. In marinating process relative amounts of fat, protein, ash increases, because of water loss by penetration of salt into meat. Containing $10 \% \mathrm{NaCl}$ and $4 \%$ acetic acid can extend the shelf life of the product in refrigerated storage conditions (Pop \& Frunză, 2015).

Application of salting or brining prior to smoking improves functional properties. Toughness and hardness are important textural attributes, and they depend on the connective tissue containing collagen, which is responsible for tensile strength and the myofibrils consisting of myosin and actin (Burgaard, 2010). Dhanapal et al. (2013) advised fish dipped in $10 \%$ salt concentration for $60 \mathrm{~min}$ were found improving the colour and textural quality based on sensory evaluation. Fish brined with $8-10 \%$ salt about an hour was sufficient to remove slime and harden the fish flesh. Brining $15 \mathrm{~min}$ in salt solution makes $1.1-1.6 \%$ as $\mathrm{NaCl}$ in finished product. Adding $25 \%$ calcium chloride to $75 \% \mathrm{NaCl}$ for 3 hour provides a proper firm texture to the meat (Zakipour Rahimabadi 
\& Faralizadeh, 2016). Cooked fish usually tend to become soft in texture comparing with raw fish, because the heat induces the conversion of collagen to gelatin in fish flesh, and darkening of the fish muscle because of Maillard reaction (Dhanapal et al., 2013).

\section{Processing conditions}

Smoking creates new products with specific sensorial characteristics and texture. Already in ancient times smoking was used as a fish preservation method, which added not only specific flavour and colour to the product, but also it made smoke compounds work as antimicrobial agents (Tahsin et al., 2017). It is critical to understand the changes occurring in the fish, because it may reduce the quality in processing.

Hot smoking is carried out in several stages, when the temperature is increased from 40 till $100^{\circ} \mathrm{C}$, while in the product it reaches at least $85^{\circ} \mathrm{C}$. The content of polycyclic aromatic hydrocarbons (PAH) depends on temperature of smoke generation (Stołyhwo \& Sikorski, 2005). The smoking itself also has a drying effect, and it decreases the water activity and increases inhibition of bacterial growth. Combination of liquid smoke with traditional smoke inhibited lipid oxidation (Sampels, 2015a).

Over 400 compounds identified in wood smoke, so far 40 acids, 22 alcohols, 131 carbonyls, 22 esters, 46 furans, 16 lactones and 75 phenols. Wood smoke contains also about 61 compounds of PAH (Stołyhwo \& Sikorski, 2005). According to the report of the European Food Safety Authority (EFSA) beech (Fagus sylvatica) wood is the most common wood used for smoking food. All smoke compounds arise during the pyrolysis of the wood compounds, and are responsible for preservation and antimicrobial effect of the smoke. The typical smoke flavour is mainly related to the phenolic compounds in the smoke. The most active wood smoke compounds in traditional smoking are pyrogallol, resorcinol, 4-methylguaiacol, less active is syringol, guaiacol (Stołyhwo, Kołodziejska, \& Sikorski, 2006). In liquid smoke, traditional compounds in smoke are syringol and cresols that give cold smoke sensory attributes. The content of syringol in hardwood smoke is higher than the content of guaiacol due to the different structure of lignin in hardwood and softwood (Hitzel et al., 2014). Toledo (2008) observed that some of phenols in smoke are similar to spices, eugenol like cinnamon, pepper, and nutmeg. The flavour of smoke components depends on concentration. Lingbeck et al. (2014) found the amount of phenols in liquid smoke condensates is about 9.9 till $11.1 \mathrm{mg} \mathrm{mL}^{-1}$. Recommended amount to use liquid smoke varies from $0.4 \%$ till $4 \%$. But smoke compounds depend on smoke generation (kind of wood, wood moisture, temperature, air quantity) (Sérot et al., 2009).

Smoking increases shelf life of fish due to dehydration; it has antimicrobial and antioxidant effects from the smoke components such as formaldehyde, phenols and carboxylic acids. Stołyhwo, Kołodziejska, \& Sikorski, (2006) found out that due to phenols ring structure with conjugated double bonds, which are able to build stable radicals, the phenolic smoke compounds have antioxidative effects, but that effect has an influence from the extent of water loss in smoking process.

The smoking decreased the content of saturated fatty acids and increased content of PUFA. The higher PUFAs content can be explained by the fact that saturated fatty acids and mono unsaturated fatty acids are largely represented in neutral lipids and are more prone to migration from processing (Zakipour Rahimabadi \& Faralizadeh, 2016). Stołyhwo, Kołodziejska, \& Sikorski, (2006) found out that by using liquid smoke the values of peroxide and TBA are lower than in traditional methods. Dry salting with addition of sugar before immersion in a liquid smoke makes product with lower oxidation, lower hardness, elasticity value (Sampels, 2015a).

After smoking the amount of most important amino acids, glycine and alanine were reduced, but glutamic acid gave fish umami taste (Swastawati et al., 2016).

Texture is also one of the important properties of thermally processed food. Heating decreased water holding capacity of the muscle which resulted in loss of the muscle tenderness (Dhanapal et al., 2013).

Colour is formed when smoke and food components react chemically at the elevated temperature and the combination of cold staining and heat induced Maillard reactions take place. Maillard and Strecker aldehydes are largely responsible for colour in smoked fish. Colour varies from golden yellow to dark brown according to the nature of the wood and intensity of smoking process (Varlet, Prost, \& Serot, 2007). Toledo (2008) researched, when the product is heated, the carbonyl compounds react with the proteins in a Maillard reaction to produce the brown colour. Cold smoked products do not change colour, because there are not enough phenols to produce a stain and the Maillard reaction does not proceed far enough to develop the colour (Toledo, 2008).

Liquid smoke is one of the methods, which is becoming popular nowadays. Liquid smoke is easy to apply and easy to control (Swastawati et al., 2012). For the use of liquid smoke, simple equipment is required, and concentration of smoke compounds is controlled. The best use is from $1 \%$ till $5 \%$. Liquid smoke has not only bactericidal, but also bacteriostatic effect, and together they act as synergic preservative. It can inhibit all pathogenic bacteria (i.e. Escherichia coli, Listeria monocytogenes, Staphylococcus aureus). As sprats belong to the Clupeidae family fish, there is naturally occurring histidine in fish flesh. 
Fish meat contains very little connective tissue and high natural cathepsin enzyme, so it is very easy to be digested by that autolysis enzyme, which makes softer the meat and makes it a good source for the growth of microorganisms - pathogenic bacteria and histamine-forming bacteria. Total bacteria count should not exceed $5 \times 10^{5} \mathrm{CFU} \mathrm{g}^{-1}$ (Dien, Montolalu, \& Berhimpon, 2019). The application of liquid smoke lowers $\mathrm{pH}(5.56-5.58)$, which is caused by organic acids of condensation in smoking process (Dien, Montolalu, \& Berhimpon, 2019). The use of liquid smoke produces high quality smoked fish products, less moisture content, and lower salt, and microbiological parameters are better compared to the traditionally smoked fish products.

\section{Conclusions}

Raw material quality and its storage conditions are the important parameters for the smoked fish quality. Better raw fish quality can be provided, when reaching low storage temperature as fast as possible after catching. The selection of proper pretreatment methods and technology can provide and ensure constant quality. Smoking conditions have a significant influence on the shelf life of product, and make changes in volatile compounds, and provide better sensory parameters and texture. Therefore, systematic research of factors and their combinations is necessary in order to achieve stable quality of smoked sprats (Sprattus sprattus balticus) from the Baltic sea.

\section{References}

Abbas, K.A., Mohamed, A., Jamilah, B., \& Ebrahimian, M. (2008). A review on correlations between fish freshness and pH during cold storage. American Journal of Biochemistry and Biotechnology, 4(4), 416421. DOI: 10.3844/ajbbsp.2008.416.421.

Bonoco, A., \& Kurt Kaya, G. (2018). Effect of brine and dry salting methods on the physicochemical and microbial quality of chub (Squalius cephalus Linnaeus, 1758). Food Science and Technology, 38, 66-70. DOI: $10.1590 / 1678-457 x .15717$.

Borderías, A.J., \& Sánchez-Alonso, I. (2011). First Processing Steps and the Quality of Wild and Farmed Fish. Journal of Food Science, 76(1), 1-5. DOI: 10.1111/j.1750-3841.2010.01900.x.

Çağlak, E. (2015). Determination of shelf life of marinade and brine injected rainbout trout (Oncorhynchus mykiss, Walbum 1792) at refrigerator conditions. Journal of Food and Health Science, 1(4), 199-2110. DOI: $10.3153 /$ jhs 15019 .

Dawson, P., Al-Jeddawi, W., \& Remington, N. (2018). Effect of Freezing on the Shelf Life of Salmon. International Journal of Food Science, 2018, 1-12. DOI: 10.1155/2018/1686121.

Dhanapal, K., Nayak, B.B., Venkateshwarlu, G., Balasubramanian, A., Devivaraprasad Reddy, A.D., \& Basu, S. (2013). Changes in Instrumental and Sensory Characteristics of Tilapia Fish Steaks During Cold Blanching and Cooking Treatments. The Bioscan, 8(3), 887-892.

Dien, H.A., Montolalu, R.I., \& Berhimpon, S. (2019). Liquid smoke inhibits growth of pathogenic and histamine forming bacteria on skipjack fillets. IOP Conference Series: Earth and Environmental Science, 278(1), 12018.

Eizenberga, I., Terentjeva, M., Valciņa, O., Novoslavskij, A., Strazdiņa, V., Ošmjana, J., \& Bērziņš, A. (2015). Microbiological quality of raw fish at retail market in Latvia. Proceedings of the $25^{\text {th }}$ NJF Congress Nordic View to Sustainable Rural Development, 16-18 Jun. 2015, pp. 324-328.

Hamada-Sato, N., Usui, K., Kobayashi, T., Imada, C., \& Watanabe, E. (2005). Quality assurance of raw fish based on HACCP concept. Food Control, 16(4), 301-307. DOI: 10.1016/j.foodcont.2004.02.001.

Herawati, E.R.N., Angwar, Susanto, A., \& Kurniadi (2016). Effect of Brine Concentration on the Nutrient Content and Fatty Acid Profile of Canned Catfish [Pangasius sutchi (Fowler, 1937)]. Aquatic Procedia, 7 , 85-91. DOI: 10.1016/j.aqpro.2016.07.011.

Hitzel, A., Pöhlmann, M., Schwägele, F., Speer, K., \& Jira, W. (2014). Polycyclic aromatic hydrocarbons (PAH) and phenolic substances in meat products smoked with different types of wood and smoking spices. Food Chemistry, 139(1-4), 955-962. DOI: 10.1016/j.foodchem.2013.02.011.

Karaçam, H., Kutlu, S., \& Köse, S. (2002). Effect of salt concentrations and temperature on the quality and shelf-life of brined anchovies. International Journal of Food Science and Technology, 37(1), 19-28. DOI: 10.1046/j.1365-2621.2002.00526.x.

Kołodziejska, I., \& Sikorski, Z. (2004). Lipid oxidation and lysine availability in smoked Atlantic mackerel fillets and Baltic sprats. Bulletin of the Sea Fisheries Institute 3 (163), 13-21.

Köse, S. (2010). Evaluation of Seafood Safety Health Hazards for Traditional Fish Products: Preventive Measures and Monitoring Issues. Turkish Journal of Fisheries and Aquatic Sciences, 10(1), $139-160$. DOI: $10.4194 /$ trjfas.2010.0120. 
Lingbeck, J.M., Cordero, P., O’Bryan, C.A., Johnson, M.G., Ricke, S.C., \& Crandall, P.G. (2014). Functionality of liquid smoke as an all-natural antimicrobial in food preservation. Meat Science, 97(2), 197-206. DOI: 10.1016/j.meatsci.2014.02.003.

Martinez, O., Salmerón, J., Guillén, M.D., \& Casas, C. (2010). Effect of freezing on the physicochemical, textural and sensorial characteristics of salmon (Salmo salar) smoked with a liquid smoke flavouring. LWT - Food Science and Technology, 43(6), 910-918. DOI: 10.1016/j.lwt.2010.01.026.

Mohanty, B.P., Mahanty, A., Ganguly, S., Mitra, T., Karunakaran, D., \& Anandan, R. (2019). Nutritional composition of food fishes and their importance in providing food and nutritional security. Food Chemistry, 293 (August 2016), 561-570. DOI: 10.1016/j.foodchem.2017.11.039.

Pawul-Gruba, M., Michalski, M., \& Osek, J. (2014). Determination of histamine in fresh and smoked fish commercially available in Poland. Bulletin of the Veterinary Institute in Pulawy, 58(2), 301-304. DOI: 10.2478 /bvip-2014-0046.

Pop, I.M., \& Frunză, G. (2015). Study on the Nutritional Quality (Scomber scomber). Scientific Papers-Animal Science Series, 65(1), 143-147.

Ruiz-Capillas, C. (2000). Quality of Frozen/Thawed Sprat (Sprattus sprattus) stored in cling film and aluminum foil at 4C. Journal of Food Quality 25, 1-11.

Sampels, S. (2015a). The effects of processing technologies and preparation on the final quality of fish products. Trends in Food Science and Technology, 44(2), 131-146. DOI: 10.1016/j.tifs.2015.04.003.

Sampels, S. (2015b). The Effects of Storage and Preservation Technologies on the Quality of Fish Products: A Review. Journal of Food Processing and Preservation, 39(6), 1206-1215. DOI: 10.1111/jfpp.12337.

Serdaroglu, M., Baris, P., Urgu, M., Doostifard, E., \& Yildiz-Turp, G. (2015). Quality changes of sardine fillets marinated with vinegar, grapefruit and pomegranate marinades. Electronic Journal of Polish Agricultural Universities. Series Food Science and Technology, 18(4) \#09.

Sérot, T., Baron, R., Cardinal, M., Catanéo, C., Knockaert, C., Bizec, B.L., Prost, C., Monteau, F., \& Varlet, V. (2009). Assessment of the effects of the smoke generation processes and of smoking parameters on the organoleptic perception, the levels of the most odorant compounds and PAH content of smoked salmon fillets. Retrieved April 19, 2020, from http:/www.fao.org/tempref/docrep/fao/012/i0884b/i0884b02b.pdf.

Solanki, J., Parmar, H., Parmar, A., Parmar, E., \& Masani, M. (2016). Freshness evaluation of fish by quality index method (QIM) and instrumental method at Veraval Fish Landing Centre. International Journal of Processing and Post-Harvest Technology, 7(1), 42-46. DOI: 10.15740/has/ijppht/7.1/42-46.

Stołyhwo,A., Kołodziejska, I., \& Sikorski,Z.E. (2006). Long chain polyunsaturated fatty acids in smoked Atlantic mackerel and Baltic sprats. Food Chemistry, 94(4), 589-595. DOI: 10.1016/j.foodchem.2004.11.050.

Stołyhwo, A., \& Sikorski, Z.E. (2005). Polycyclic aromatic hydrocarbons in smoked fish - A critical review. Food Chemistry, 91(2), 303-311. DOI: 10.1016/j.foodchem.2004.06.012.

Swastawati, F., Boesono, H., Susanto, E., \& Setyastuti, A.I. (2016). Changes of Amino Acids and Quality in Smoked Milkfish [Chanos chanos (Forskal 1775)] Processed by Different Redestilation Methods of Corncob Liquid Smoke. Aquatic Procedia, 7, 100-105. DOI: 10.1016/j.aqpro.2016.07.013.

Swastawati, F., Susanto, E., Cahyono, B., \& Trilaksono, W.A. (2012). Sensory Evaluation and Chemical Characteristics of Smoked Stingray (Dasyatis Blekeery) Processed by Using Two Different Liquid Smoke. International Journal of Bioscience, Biochemistry and Bioinformatics, (November 2016), 212-216. DOI: 10.7763/ijbbb.2012.v2.103.

Tahsin, K.N., Soad, A.R., Ali, A.M., \& Moury, I.J. (2017). A Review on the Techniques for Quality Assurance of Fish and Fish Products. International Journal of Advanced Research in Science and Engineering, 4, 4190-4206.

Timberg, L., Koppel, K., Kuldjärv, R., \& Paalme, T. (2011). Sensory and chemical properties of Baltic sprat (Sprattus sprattus balticus) and Baltic herring (Clupea harengus membras) in different catching seasons. Agronomy Research, 9((Special Issue II), 489-494.

Timberg, L., Koppel, K., Kuldjärv, R., \& Paalme, T. (2014). Ripening and sensory properties of spice-cured sprats and sensory properties development. Journal of Aquatic Food Product Technology, 23(2), $129-145$. DOI: $10.1080 / 10498850.2012 .700003$.

Toledo, R.T. (2008). Wood Smoke Components and Functional Properties. In: D.E. Kramer and L. Brown (eds.), International Smoked Seafood Conference Proceedings. Alaska Sea Grant College Program, Fairbanks, pp. 55-61. DOI: 10.4027/isscp.2008.12.

Usydus, Z., Szlifder-Richert, J., \& Adamczyk, M. (2012). Variations in proximate composition and fatty acid profiles of Baltic sprat (Sprattus sprattus balticus). Food Chemistry, 130(1), 97-103. DOI: 10.1016/j. foodchem.2011.07.003. 
Varlet, V., Prost, C., \& Serot, T. (2007). Volatile aldehydes in smoked fish: Analysis methods, occurence and mechanisms of formation. Food Chemistry, 105(4), 1536-1556. DOI: 10.1016/j.foodchem.2007.03.041.

Wu, L., Pu, H., \& Sun, D.W. (2019). Novel techniques for evaluating freshness quality attributes of fish: A review of recent developments. Trends in Food Science and Technology, 83(July 2018), 259-273. DOI: 10.1016/j.tifs.2018.12.002.

Yanar, Y., Çelik, M., \& Akamca, E. (2006). Effects of brine concentration on shelf-life of hot-smoked tilapia (Oreochromis niloticus) stored at $4{ }^{\circ} \mathrm{C}$. Food Chemistry, 97(2), 244-247. DOI: 10.1016/j. foodchem.2005.03.043.

Zakipour Rahimabadi, E., \& Faralizadeh, S. (2016). Fatty acid composition of fresh and smoked Black and Caspian Sea sprat, Clupeonella cultriventris (Nordmann, 1840) treated with different salt composition. Caspian Journal of Environmental Sciences, 14(2), 117-124.

Zugarramurdi, A., Parin, M.A., Gadaleta, L., Carrizo, G., \& Lupin, H.M. (2004). The effect of improving raw material quality on product quality and operating costs: A comparative study for lean and fatty fish. Food Control, 15(7), 503-509. DOI: 10.1016/j.foodcont.2003.08.001. 